\title{
THE DEEP ECOLOGY PERSEPECTIVE OF AWIG-AWIG: LOCAL TRIBAL FOREST PRESERVATION LAWS IN TENGANAN CULTURAL VILLAGE, INDONESIA
}

\author{
SUMARMI $^{1}$, SYAMSUL BACHRI ${ }^{1}$, TUTI MUTIA*2, ARISIUS YUSTESIA ${ }^{3.5}$, MUHAMMAD \\ NAUFAL FATHONI ${ }^{3}$, MUHAMMMAD AUNAL MUTHI ${ }^{3}$, AND SISMI GUSTY NURAINI ${ }^{3}$ \\ ${ }^{1}$ Department of Geography Education Faculty of Social Sciences Universitas Negeri Malang. ${ }^{2}$ Department of Geography \\ Education Faculty of Education Universitas Hamzanwadi Selong. ${ }^{3}$ Doctoral Student Department of Geography Education \\ Universitas Negeri Malang. ${ }^{4}$ Bachelor Student Department of Geography Faculty of Social Sciences Universitas Negeri \\ Malang. ${ }^{5}$ Department of Geography Education STKIP Kie Raha Ternate.
}

*Corresponding author: mutiatia92@yahoo.co.id

Submitted final draft: 25 April $2020 \quad$ Accepted: 24 May 2020

http://doi.org/10.46754/jssm.2020.12.009

\begin{abstract}
Tenganan indigenous people's awig-awig forest preservation is still used and considered effective in maintaining the existence of forests. The existence of sustainable forests in Tenganan Village play an important role in groundwater regulation, biodiversity protection, landslide prevention, oxygen generation and climate balance control. The purpose of this study is to describe forest conservation through Tenganan indigenous people's awig-awig based on deep ecology and to reveal ways to preserve awig-awig related to forest conservation. The research was conducted qualitatively by using in-depth interview, participant observation, and documentation as data collection. The data are analysed in four processes, namely reduction, categorisation, synthesis and conclusion. The results show that the community cannot be separated from awig-awig. Tenganan indigenous people conserve awig-awig related to forest conservation by means of socialisation from family, community and traditional education (metruna nyoman), law enforcement and ritual. Forest conservation with awig-awig can sustain the existence of forests.
\end{abstract}

Keywords: Forest conservation, environment, indigenous people, awig-awig, deep ecology.

\section{Introduction}

Environmental conservation, specifically of forests, is a traditional, contemporary, and modern issue. The issue per se remains a problem at the local, national and international levels to this day. The declining quality of the environment related to forest resources in the last few years is a topic that is often discussed and requires attention from national to international level (Lestari et al. 2014). Forest conservation is essential to maintain the sustainability of forest functions. Conservation and sustainability have been the concern of the entire world community in dealing with forest degradation (Kausar 2010). Conservation of natural resources, for example forests, is highly dependent on the participation of local communities around the forest. Local community participation in forest management aims to prevent forest destruction (Sahlan 2012; Wibowo et al. 2012; Magdalena,
2013; Ginting et al. 2015). The participation of local communities in forest conservation is based on knowledge and norms passed on from their ancestors, which are local wisdom that encourages people to voluntarily and collectively participate in forest conservation as a source of their welfare (Purba, 2005; Marfa'I, 2012; Sahlan, 2012).

Local wisdom is a cultural heritage and a form of environmental wisdom among people of the community in a place or area. Environmental wisdom takes the form of wise ideas used both as a guide for the community in conserving natural resources and a form of environmental justice (Salain, 2004). The response of the interaction between man and the environment is a manifestation of local wisdom. Local wisdom is the result of the interaction of the physical and social environment in the form of ideas, customs, activities, materials and equipment as a result 
of abstraction of environmental management (Marfa'I, 2012) and it can serve as a guide that directs human behaviour and actions to the environment. The functions of local wisdom are environmental conservation and maintenance which aim to preserve the existence and function of the forest so as to provide benefits both in the present and the future. $30 \%$ indigenous forest in Indonesia is preserved by indigenous peoples within their local wisdom (Nuari, 2016). Therefore, indigenous people play an important part of in Indonesia in conserving natural resources, especially forests.

Indigenous peoples have a strong motivation in protecting the forests compared to others because forests are a source of their sustainability. Indigenous peoples protect forests with their original knowledge or local wisdom on maintaining and utilising existing forests in their habitat (Nuari ,2016). The Tenganan indigenous people, one of the existing indigenous people in Indonesia, for example, still use the local wisdom in preserving the forest resources, and their unique way of preserving the forests is governed by customary institutions (krama desa) with customary laws/rules known as awigawig which regulate harmonious interactions between communities and forest ecosystems. Thus, Tenganan indigenous forest is still preserved to date, proven to assist communities in meeting ecological needs. The research on the conservation of forests with local wisdom conducted in Pakpak ethnic, in North Sumatra (Hidayat, 2011) Ban Nong Hua Khon Tribe, and Tambon Nong Muen Than, in Thailand (Burrirat \& Thamsenamu, 2010) revealed that forest preservation with local wisdom has a positive impact on the environment.

The preservation of Tenganan indigenous forest is implemented in their local wisdom awig-awig. Awig-awig forest conservation is manifested from community ethics towards forests and local wisdom is integrated from several aspects such as knowledge, belief, insight and ethics that guide human behaviour in ecology (Sumarmi \& Amiruddin, 2014). Environmental ethics is the moral wisdom of humans in interacting with their environment and is the result of a critical reflection on what humans should do in the face of moral choices to meet the needs of life on the norms and moral values known in the community (Keraf, 2010). Consequently, environmental ethics is needed to carefully consider the actions taken to maintain the balance of the environment. In addition, environmental ethics as an approach that views the environment and all life as having equal standing and mutual support and is called deep ecology. Naess (1989) concluded that environmental ethics that focuses on all species and long-term ecological community is defined as the concept of deep ecology (Barnhill et al., 2001).

The ecological approach views that all life must be kept in balance. To achieve a balance of nature, environmental ethics has an important role. Deep ecology regulates life in harmony with nature based on community wisdom (Satmaidi, 2016). Wisdom is one of the perspectives and behavior of indigenous peoples interacting with nature (Naess 1989; Keraf 2010). Such interactions are reflected in the Tenganan community in conserving forests and their principle is that nature has value in life. This relates to the principles of deep ecology, namely (a) the respect of all the ways and forms of life in the universe, (b) all species have the same value (c) self-realisation, (d) the recognition and appreciation of the diversity and ecological complexity in a symbiotic relationship, and (e) political change towards ecopolitics (Naess, 1989).

Behavior in interacting with the environment is influenced by the local knowledge that exists somewhere. Deep ecology is the way in protecting the environment and mitigating the exploitative nature of man against nature by raising local knowledge that is solution-based (Dwi \& Rachmat 2008; Mutia et al., 2019). Therefore, it is important for the preservation of the wisdom in keeping the sustainability of the forest. With a description of the local wisdom of the Tenganan indigenous people, the writer was interested to examine forest conservation carried out with their local knowledge of awig awig, using deep ecology to preserve forests. 
The purpose of this study was to describe the indigenous forest conservation of the Tenganan with awig awig based approach, revealing deep ecology and conservation in indigenous forest conservation.

\section{Methods}

This research is a qualitative descriptive research which tries to describe in detail the preservation of Tenganan indigenous people's awig-awig forest conservation based on principles of deep ecology. Deep ecology is a concept of environmental ethics that views all elements of life both biotic and abiotic which have the same position and all these elements must be respected and preserved.

\section{Study Areas}

This research was conducted in Tenganan Village, Manggis District, Karangasem Regency, Bali Province, Indonesia. The location of the research can be seen in Figure 1.

\section{Data Collection Procedures}

The data in this study were collected through participant observation, in-depth interviews and documentation. This research data are related to the preservation of forests with awig-awig and ways to preserve awig-awig among Tenganan indigenous people. The informants were 25 people as the unit of analysis in this research selected through purposive sampling technique based on the group representation, namely the village krama, village head and the Tenganan indigenous people. Village krama is the key informant, while supporting informants consist of the indigenous peoples and the Tenganan village head.

\section{Data Analysis}

Data analysis in this research uses analysis component and data interpretation. Analysis and interpretation of data consist of four processes namely reduction, categorisation, synthesis and conclusion. The process of data analysis can be seen in Figure 2.

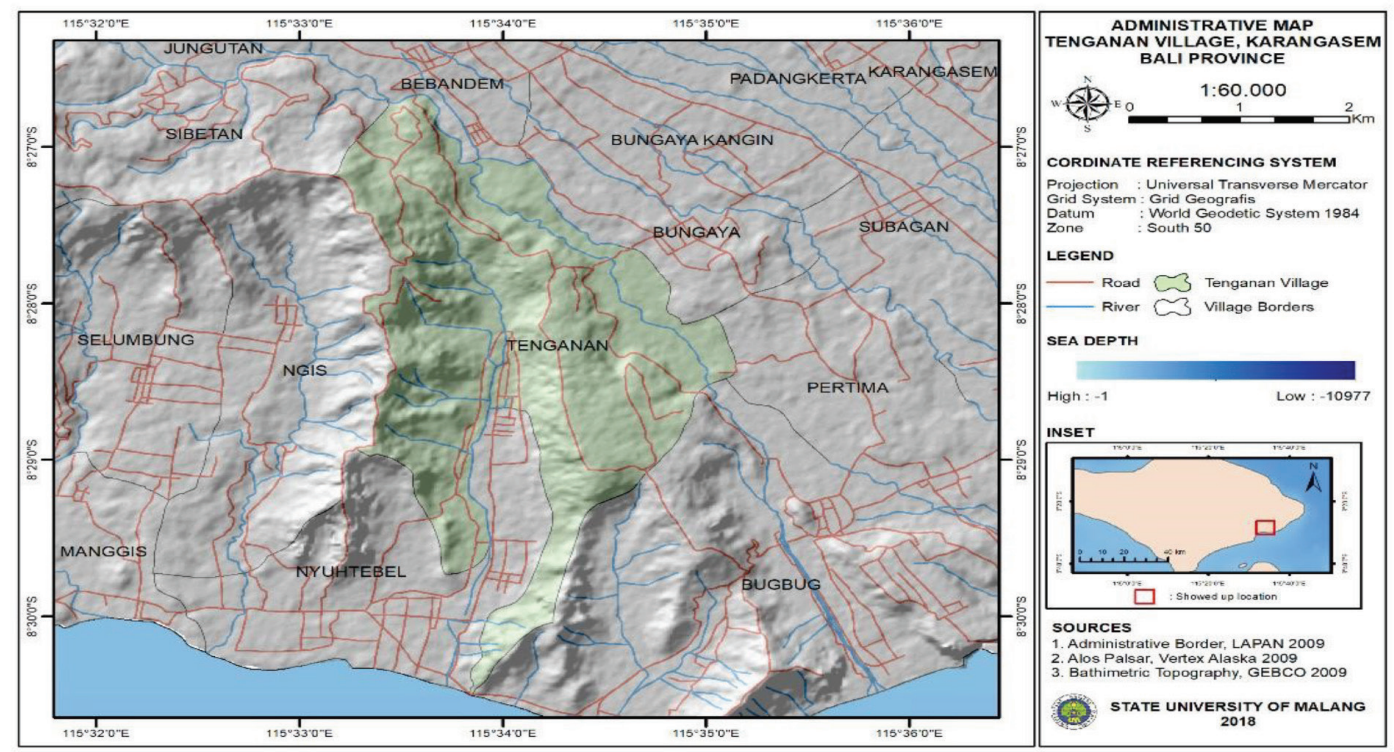

Figure 1: Map of research location 


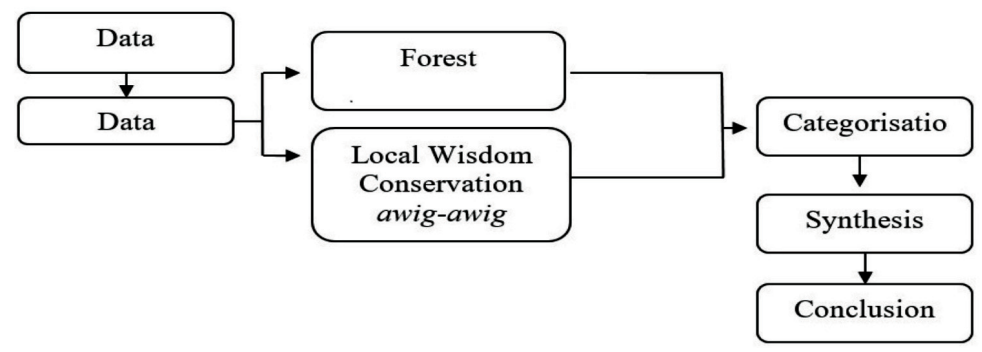

Figure 2: Data analysis process

\section{Result and Discussion}

\section{Characteristics of Research Areas}

Tenganan Cultural Village is administratively included in the Manggis Subdistrict, Karangasem Regency with boundaries as follows: Ngis Village in the West; Macang and Bebandem Village in the North; Bungaya, Asak, and Timrah Village in the East; and Pasedahan and Tebel Village in the south. Physiographically, it is surrounded by semi-circular hills. The hills limit the northern, eastern, and western parts of the village, while the southern part is directly adjacent to the lowlands and the sea. The indigenous people of Tenganan consider the hills a sacred area, but in the perspective of disaster mitigation, the area is a catchment area.
If there is forest destruction in the Tenganan Village, disaster, such as a landslide, will occur.

The Tenganan Village area is 917,200 ha with 255,840 ha of paddy fields and the dry land (forest and tegal) covers 583,035 ha, while the remaining 78,325 ha is occupied by settlements and other social facilities. Economic activities of the people in Tenganan Village are agriculture and trade and farming activities are carried out by farm owners and farmers. They make use of the natural environment or forests to carry out their daily activities, so that trees and plants are protected and conserved by the people. The condition of the forest area and settlement of the cultural village can be seen in Figure 3 below.

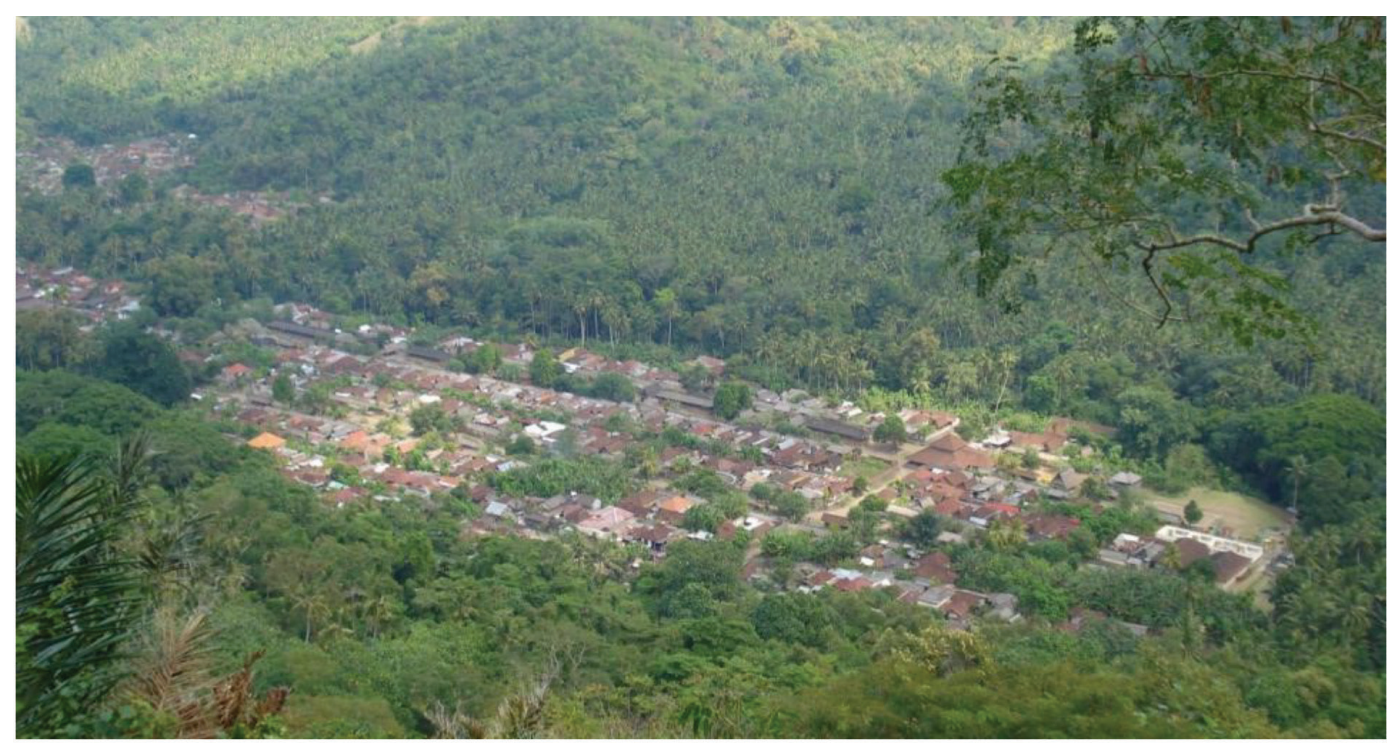

Figure 3: Forest and residential areas of Tenganan Cultural Village 
Forest Conservation by the Tenganan Indigenous Peoples Through Awig-awig Based on Principles of Deep Ecology

Forest preservation carried out by the indigenous peoples of Tenganan is based on customary rules known as awig-awig and which are manifested through their behaviour towards the forest. Preservation of the forest is reflected in the form of the community's behaviour (Irawan et al. 2017; Odorellina et al. 2015; Ohorella et al. 2011; Syarif et al. 2016). Awig-awig prohibits the cutting of trees without the permission of the village krama However, logging can be done by fulfilling some of the requirements set by awigawig. In accordance with this, a key informant stated as follows:

"The ban on cutting trees on Tenganan indigenous people is their way of preserving the forests which is set forth in the customary rules called awigawig. Forest preservation by Tenganan indigenous peoples is reflected in the community's behaviour towards forests."

In addition, Informant 1 stated that:

"They exploit the forest resources based on life lessons that the natural wealth is not only for them, but also for the next generation."

These rules contain the concept of respect for nature which should not to be undermined. Deep ecology views human beings and nature as having an equal position. It emphasises that the use of natural resources must be meaningful and profound and it provides a strong foundation of moral ethics as human basic which is obliged to maintain and protect the environment including the forest (Drengson et al., 2011; Keraf 2010).

Protection of forests in the Tenganan community is done by adherence to awig-awig. This form of compliance provides an overview of the very rare behaviour of cutting trees for 10 years. Since 2008, there has been no reporting of illegal logging on customary, private and communal lands. This cannot be separated from the awareness within the Tenganan community that the cutting of trees can damage the environment. Forest exploitation and illegal logging occur in developing countries, including Indonesia, cause forest destruction (Aryadi, 2000; Poffenberger, 2006). These indigenous peoples do not cut trees and they have a habit of replanting similar trees after logging which demonstrates a form of forest conservation effort. In addition, conservation is also done, taken into consideration that the Tenganan village is in between the hills, so that when there is destruction to the forest landslides will possibly occur. According to an informant:

"They are also very aware of the
importance of forest preservation,
given that the village is made of $80 \%$
forest and villages are in between
the hills. This encourages Tenganan
indigenous peoples to behave friendly
to the environment and forests."

This is in accordance with the principle of deep ecology regarding self-realisation and assumes that man can realize it himself by developing the potential within him to be able to sustain his life (Keraf, 2010). The Tenganan community develops its potential to sustain, for example, through forest preservation with customary rules as their local knowledge. Forest sustainability is highly dependent on communities living in the forest who depend on the forests for their livelihoods, in both economic and ecological terms (Ginting et al., 2015). The local knowledge held by this community, embodied in their direct forest behaviour, has a positive effect on the existence of forests and their environment. Similar research results are also found in the Togutil Tribe, Halmahera (Tamelene et al., 2014) and communities in South Korea (Youn, 2009) who are able to protect and conserve forests with local or traditional knowledge. The sustainability of the Tenganan indigenous forest can be seen in Figure 4.

The sustainable forest condition in Figure 4 has a positive effect on the environment. The condition of the environment of Tenganan Village cannot be separated from the good interaction between the Tenganan community 


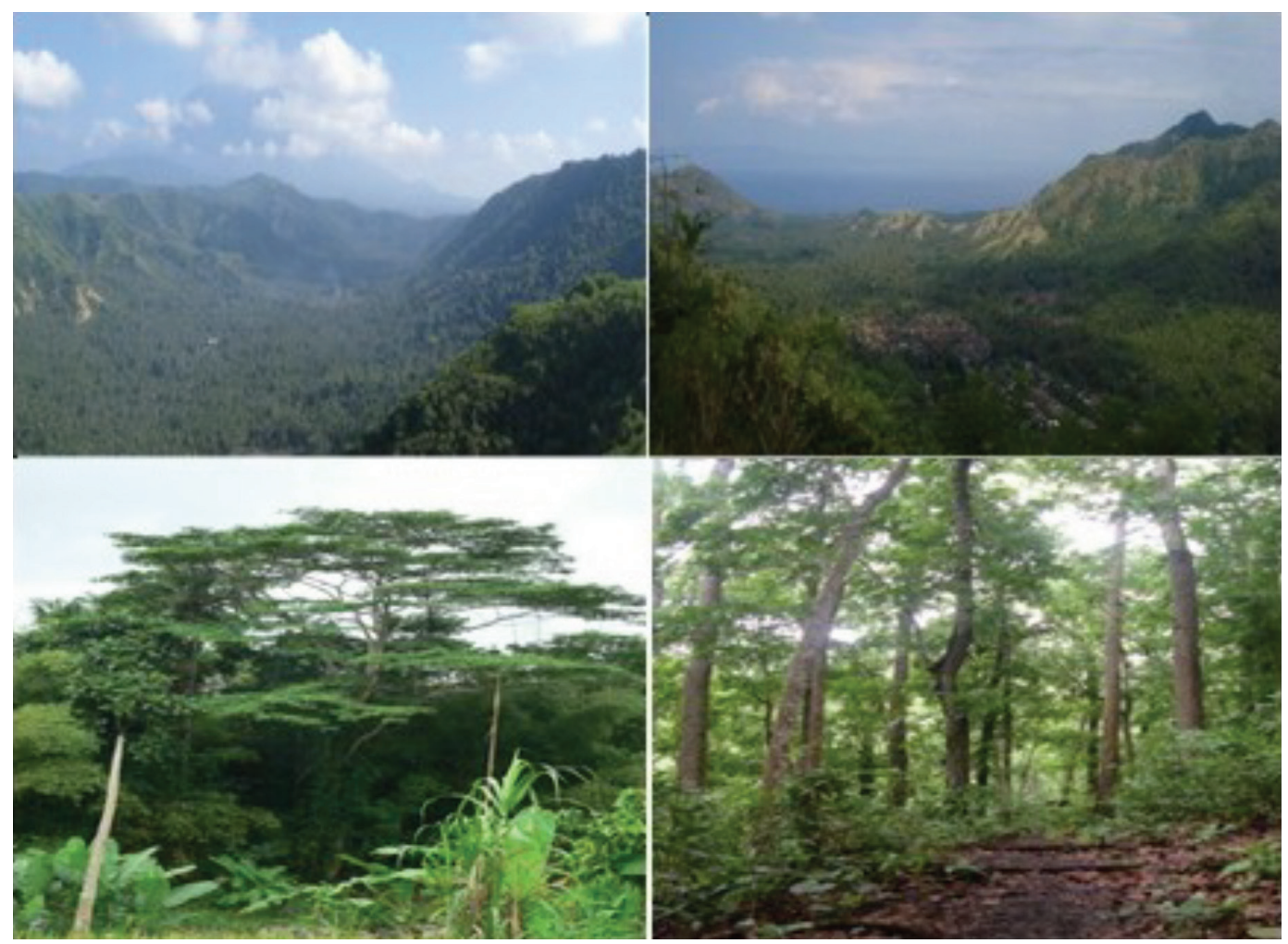

Figure 4: Forest Condition of Tenganan Village

and the forest, be it directly or indirectly. This interaction occurs because they are heavily dependent on the forests, for example in the utilization of forest products for large ceremonies and home building materials for new marriages. Large ceremonies in the Balinese community generally involved the act of split contribution to be submitted for customary activities. Nevertheless, it is quite different in the Tenganan communities as they are only assigned to harvest the forest products to be used in the ceremony. In traditional ceremonies, a lot of natural resources are used (Ridhwan, 2012). The existence of activities, such as logging timber for the purpose of building a house for a new marriage, provides convenience for the Tenganan community. and in turn encourages them to preserve their forests as a way of adaptation for their survival. Tanjung (1992) stated that local wisdom means knowledge possessed by the community in managing the environment, which is knowledge that breeds behaviour as a result of their adaptation to their environment (Ginting et al., 2015).

The diversity of adaptation patterns to the environment in Indonesian society is inherited from generation to generation as a guide in utilizing resources (Suhartini, 2009). The rights of Tenganan forest resource utilization based on awig-awig can be done within four terms, namely penaho, pengapih, tumapung, and ulungan. The following statement is from informant 4 and is as follows:

"The felling of adjacent trees may be applied to the Tenganan indigenous people for thinning, but this activity cannot be separated from the approval of the village krama. The permission for logging and fruit picking is related to the utilization of forest resources. The beneficiaries of these forest resources have rules or rights that are called penaho, pengapih, tumapung and ulungan." 
Penaho is the permission to cut the trees either in the forest or in tegal (forest) to the village krama's (customary structures) permit for dead trees. Pengapih or thinning is the permission to cut trees of the same type and growing close together, of three trees lined in which the middle may be cut. Tumapung is the right to cut down the tree for building materials needed to build a Bale Tengah for the new / young family on their own land. Ulungan is a customary rule where people cannot pick four kinds of fruits (durian and candlenut) over the tree. After the fruits have ripened and fallen off all the indigenous villagers are entitled to pick them. All the loggers' permits are not separated from the approval of the village krama. Logging permit through the registration mechanism is done by paying 2000 rupiah and the logging permit would take note on the type of wood, location, owner's name, and name of the farmer. All permits to loggers or for the utilization of forest resources cannot be separated from the approval of village krama. In accordance with this the statement from Informant 4 is as follows:

\begin{abstract}
"Communities committing awig-awig violations will face sanctions or pay penalties on the village authorities and the complainant. The village is given $50 \%$ so is the complainant and then granted to the village for customary events. Based on awig-awig, sanctions against such violations were decided by the village klian as the cultural village chairman. If the village klian is unable to decide on appropriate sanctions against violators, then the opinion of the luanan as advisors will be asked among the village karma (customary structure)."
\end{abstract}

If there is a violation of the rules, the application of sanctions on the violators is also done by the customary institutions and violators who cut down trees without customary permits, will have to return the taken timber and then will have to be bought at twice the price (rupiah currency at the price of wood at the time). If the violator has a position, then the position will be revoked and excommunicated and become public disgust. This is in accordance with the statement of Informant 2 below:

"When Tenganan indigenous peoples cut down the forbidden trees such as candlenut, cempaka, teep, jaka (aren) without the permission of customary leaders, the timber should be taken back and be paid twice the price of logged timber and 40-75 thousand kepeng (1 kepeng is worth 6000 rupiah). If a person from outside the village picks a forbidden fruit, then the person is charged 10 catu for a picker and 10 catu for a picking fine (10 catu is equivalent to $25 \mathrm{~kg}$ of rice)."

The application of sanctions contains several values, one of which is responsibility and justice for living things such as trees. In addition, Tenganan people also always perform rituals in the forest called tumpe' wariga as a forest conservation effort because they pray for the safety of the forest to be protected and remain sustainable. This is in accordance with the expression from the key informant.

"Forest conservation is also done by Tenganan indigenous people by performing tumpe' wariga rituals in the forest."

This ritual concept views plants as humans who are believed to have souls in the sense that plants are also entitled to life. Traditional rituals are a form of communication related to cooperative social relations between communities (Palmer \& Pomianek, 2007). One of the principles of deep ecology is recognising and respecting diversity and ecological complexity in a mutually beneficial symbiotic relationship with a fair attitude towards all life forms (Keraf, 2010).

Deep ecology principles can be used as a strategy for sustainable forest conservation and the foundation of sustainable ecology which consists of five principles (a) respect for all ways and forms of life in nature (biospheric egalitarianism-in principle); this behaviour 
is reflected in the actions of the Tenganan communities that do not destroy the forest but preserve the forest by not cutting trees secretly (b) humans are only one species among so many other species. All these species have the same value (non-anthropocentrism-in principle) as in this case, the behaviour of the Tenganan indigenous people in utilizing forest products through awig-awig rules with permission from the village krama and keeping to the requirement. This implies that the tree as a living being has the same position so it is not treated arbitrarily (c) the principle of self-realisation which views man not only as a social animal, but also an ecological animal and the indigenous peoples realize that by developing their potential to conserve forests on the basis of awig-awig they can sustain life (d) recognition and respect for ecological diversity and complexity in a symbiotic relationship and this form of principle which is in accordance with the awig-awig rule is in the enforcement of sanctions such as awig-awig violations by cutting trees without permission from the village karma, which will be penalized by taking back the timber taken and paying a fine twice the price of logged timber, and (e) changes in politics towards ecopolitics, which is more to the enforcement of the exploitation of the excessive use of forest resources. Awig-awig regulates all utilization of forest products aimed at sustainability of forest functions. Deep ecology has the concept of environmental protection and sustainability by humankind and environmental sustainability dedicated by the entire ecological community (Satmaidi, 2016).

Forest sustainability provides many great benefits to life. The benefits of sustainable forests include preventing erosion, preventing drought by providing water sources for irrigation, avoiding landslides, producing timber and being climate balance guards. The trees in the forest are able to balance the climate (Cohen et al., 1998; Dyanna \& Fikret, 2011; Thomas \& Kitzmiller, 2014). The forests also function for the absorption of carbon dioxide gas presented in the atmosphere, processed and removed as oxygen for human and animal respiration. Forests and trees are the lifeblood that protects the land, provides nutrients and renewable energy for hundreds of millions of people, for without this service the food system will be vulnerable which in turn affects the lack of basic needs of life (Nuari 2016). Given that fact, humans desperately need forests for their sustainability that the forest existence must be maintained by preserving it.

\section{How to preserve awig-awig related to Tenganan forest conservation}

Passing and preserving the Tenganan Village's awig-awig are done through several things which are as follows:

\section{Awig-awig Socialisation}

Awig awig socialisation activities are aimed at introducing and improving children's early understanding of local wisdom. These activities are done through family, community and traditional education and are known as metruna nyoman. Socialisation in the family is instrumental in providing an understanding of awig-awig through traditional education, metruna nyoman, which must be followed by youth of the Tenganan Village before their marriage. In accordance with this, the following statements are from Informant 1:

"The very influential agent in the conservation of the local wisdom awig awig is family. Parents introduce and provide awig-awig-related understandings in forest conservation to their children. They socialise it through the interaction in everyday life. This usually happens when there are issues of awig-awig violation which is easily spread out as a conversation of society heard by children."

In addition, also key informant states that:

"The local wisdom awig-awig related to forest conservation on Tenganan indigenous people is introduced early in childhood, gained from generation to generation in family, community and traditional education (metruna nyoman)." 
Then, it is highlighted further by informant 3 as follows:

"Knowledge of local wisdom is also obtained from traditional education of metruna nyoman which must be followed by the youth of the Tenganan community before marriage. This activity aims to introduce various customs in Tenganan, for example, the custom rule related to forest conservation that is, awig-awig."

The purpose of this activity is to introduce the customs that prevail in Tenganan Village, for example awig-awig. Awig awig socialisation with metruna nyoman is done through narration or lecture to the participants and recounting cases of awig-awig violation that have occurred. The metruna nyoman is carried out for one year and participants are given material about life and costums. One of the activities in metruna nyoman related to forest conservation is called ngintarang ketekung. This is in accordance with what was shared by informant 2 :

"Metruna nyoman activities also consist of a meditation activity known as ngintaran ketekung where the participants meditate around all the temples in Tenganan and review the area of Tenganan traditional Village to know the state of their territory. Activities in Tenganan traditional

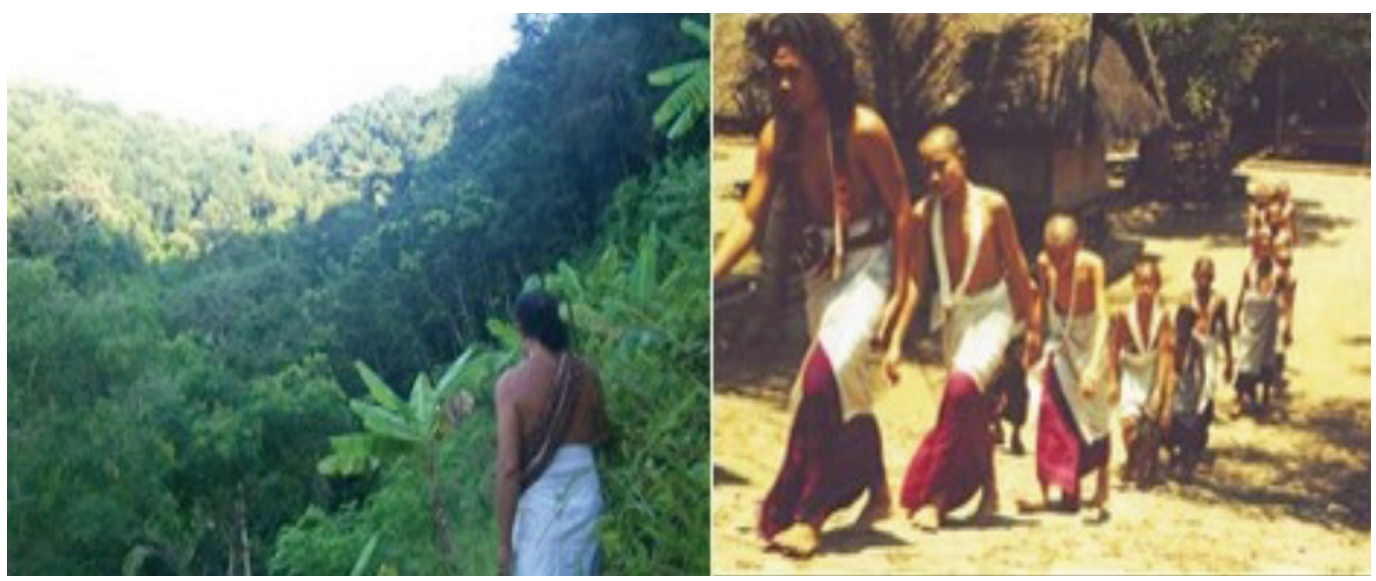

Figure 5: Participants Metruna Nyoman doing one of metruna nyoman's activities which is Ngintarang Ketekung village are also not separated from the rituals and customary ceremonies."

In this activity, participants are invited to surround the Tenganan Village area including the forest and this activity of a forest visit is metruna nyoman and this can be seen in Figure 5.

\section{Enforcement of customary law}

Aside from socialisation, preservation of Awig awig is done through enforcement of sanctions. Sanctions are granted to awig-awig offenders. The imposition of sanctions is more severe for offenders who are the villagers, because they will be deprived of their status and ostracized by the community. The enforcement of customary law in the form of sanctions is still used for generations to date and is contained in awig-awig and agreed by the village krama. Customary law enforcement has a positive impact because the community is afraid to violate awig-awig, such as tree felling, as the consequences will be quite heavy.

\section{Ritual (Ceremony)}

Maintaining and preserving awig awig is also done through rituals or ceremonies performed by the Tenganan community. This is based on information from Informant 4:

"For the Tenganan indigenous people, forest conservation cannot be separated from rituals in the forest, rituals 
and ceremonies are mediation of introducing and preserving their local wisdom. Rituals, associated with forest conservation which are called tumpe 'wariga, aim to respect the nature that has generated prosperity."

When they perform rituals related to forest conservation, the children usually ask for some things related to forest conservation. In this activity they are equipped with knowledge about awig-awig in preserving the forest. This is because awig awig contributes greatly to conserve forests.

\section{Conclusion}

Based on the result of the research, it can be concluded that the preservation of Tenganan forest based on awig-awig is in accordance with the principle of deep ecology which has been able to maintain the sustainability of the forest so that it is beneficial to ecology both economically and culturally. The conservation of awig-awig in forest conservation needs to be maintained because it has a positive effect on forests. The preservation of awig-awig is done through socialisation in family, society and traditional education (metruna nyoman), law enforcement and rituals. The strategy of sustainable forest conservation with awigawig is based on the concept of deep ecology including several points, namely the prohibition of cutting down trees, the utilization of forests through several conditions and processes related to the forest which cannot be separated from the involvement of the village krama. These points contain aspects of forest protection so that forests remain sustainable up to the present time.

\section{Acknowledgments}

The authors would like to thank all Tenganan indigenous people in the study area who generously participated in this research.

\section{References}

Aryadi. (2000). Saving Forest Remains in Indonesia. Jakarta: Yayasan Obor Indonesia
Barnhill, D. L. \& Gottlieb, R. S. 2001. Deep Ecology and World Religions: New Essays on Sacred Ground. State University of New York: Albany

Burirat, S., \& Thamsenamu, P. (2010) A Study of Local Wisdom in Management of the Community Forest in Ban Nong Hua Khon, Tambon Nong Muen Than, At Samat District, Roi-Et Province. Pakistan Journal Of Social Science, https://doi.org/10.3923/ pjssci.2010.123.128.

Cohen, S., Demeritt, D., Robinson, J., \& Rothman, D. (1998). Climate Change and Sustainable Development: Towards Dialogue. Global Environ Change, 8(4), 341-371.

Drengson, A., Devall, B., \& Schroll, M. A. (2011). The Deep Ecology Movement: Origins, Development, and Future Prospects (Toward a Transpersonal Ecosophy. International Journal of Transpersonal Studies, 3(1-2), 101-117

Dyanna, R., \& Fikret, B. (2001). Contributions of traditional knowledge to understanding climate change in the Canadian Arctic. Polar Record, 37(203), 315-328.

Dwi, S., \& Rachmad, K. (2008). Sosiologi Lingkungan. Jakarta: PT. Raja Grafindo Persada.

Ginting, K. B., Purwoko, A., \& Simanjuntak, J. (2015). Local Wisdom in Forest Management in Serdang Village, Barusjahe District, Karo Regency (In Indonesia). Peronema Forestry Science Journal, 4(4), 186-199.

Hidayat. (2011). "Natural Resource Management Based on Local Institutions". Jurnal Sejarah Citra Lekha, 15(1), 19-32.

Irawan, A., Iwanuddin., Halawane, J. E., \& Ekawati, S. (2017). Perception and Behavior Analysis of the Community towards the Existence of the Poph Model Kphp Area (In Indonesia). Jurnal Penelitian Sosial dan Ekonomi Kehutanan, 14(1), 71-82 
Kausar. (2010). Conflict Of Interest Behind Study Conservation in The Kerinci Seblat National Park (TNKS) Jambi Province (In Indonesia). Indonesian Journal of Agricultural Economics (IJAE), 2(1), 132149

Keraf. (2010), Environmental Ethics (In Indonesia). Jakarta: Buku Kompas

Lestari, T., Agussabti., \& Alibasyah, M. R. (2014). Indigenous Community Participation in Forest Resource Conservation in Jantho City District, Aceh Besar District (In Indonesia). Jurnal Manajemen Sumberdaya Lahan, 3(2), 506517

Magdalena, M. (2013). The Role of Customary Law in Forest Management and Protection in Sesaot Village, West Nusa Tenggara and Setulang Village, East Kalimantan (In Indonesia). Jurnal Penelitian Sosial dan Ekonomi Kehutanan, 10(2), 110 - 121

Marfa'i, M. A. (2012). Introduction to Environmental Ethics and Local Wisdom (In Indonesia). Yogyakarta: Gadjah Mada University Press

Mutia, T., Sumarmi., Budijanto., \& Bachri, S. (2019). Konservasi Masyarakat Adat Bayan: Awiq-awiq Dalam Perspektif Deep Ecology. Malang: UM Press

Naess, A. (1989). Ecology, Community and Lifestyle. United Kingdom: Cambridge University Press.

Nuari, P. Z. (2016). Local Minangkabau Local Wisdom in Preserving Wet Tropical Forests in Harau District, Limapuluh Kota Regency, West Sumatra Province (In Indonesia). Proceedings of the National Seminar on "Environmental Conservation \& Disaster Mitigation" Pekanbaru, Riau: University Of Riau

Odorellina, R., Situmorang, P., \& Simanjuntak, R. (2015). Local Wisdom in Managing Forests by Communities in the Area of Tourism Areas in Sicike-Cike North Sumatra (In Indonesia). Widyariset, 18(1), 145-154
Ohorella, S., Suharjito, D., \& Ichwandi, I. (2011). Effectiveness of Local Institutions in the Management of Forest Resources in the Rumahkay Community in West Seram District, Maluku (In Indonesia). Jurnal Manajemen Hutan Tropis, 17(2), 49-55

Palmer, C. T., \& Pomianek, C. N. (2007) Applying Signaling Theory to Traditional Cultural Rituals : The Example of Newfoundland Mumming. Human Nature, 18(4), 295-312, https://doi.org/10.1007/ s12110-007-9020-2

Poffenberger, M. (2006) People in the forest: community forestr y experiences from Southeast Asia. International Journal Environment Sustainability Development, https://doi.org/10.1504/ IJESD.2006.008683

Purba, J. (2005). Social Environment Management In Indonesia. Jakarta: Yayasan Obor Indonesia

Ridhwan, M. (2012). Level of Biodiversity and Its Utilization in Indonesia. Jurnal Biology Education Universitas Serambi Mekkah, 1(1), 1-4

Sahlan. (2012). Local Wisdom of the Tau Taa Wana Bulang Community in Conservation of Forest in Central Sulawesi Province (Doctoral dissertation). https://doi. org/10.22146/jmh.16136 (accessed 05.06.18)

Salain, P. R. 2004. Konsep Tata Ruang yang Berwawasan Budaya: Suatu Kajian Kasus Kota Denpasar. Denpasar.

Satmaidi, E. (2016). Deep Ecology Concept in Environmental Law Settings (In Indonesia). Jurnal Supremasi Hukum, 24(2), 191-200.

Suhartini. (2009). Study of Community Local Wisdom in the Management of Natural Resources and the Environment (In IIndonesia). Proceedings of the National Seminar on Research, Education and Implementation of Mathematics and Natural Sciences, Faculty of Mathematics and 
Natural Sciences, Faculty of Mathematics and Natural Sciences: Yogyakarta State University.

Sumarmi., \& Amiruddin, A. (2014). Environmental Management Based on Local Wisdom (In Indonesia). Malang: Aditya Media Publishing

Syarif, E., Fatchan, A., Sumarmi., \& Astina, I. K. (2016). Indigenous Forests and Community Ammatoa (Overview in the Pasang ri Kajang Perspective) (In Indonesia). Malang: Aditya Media Publishing

Tamelene, M. N., Muhdhar, M. H. I. A., Suarsini, E., \& Rochman, F. (2014). The Practice of Local Wisdom of Tobelo Dalam (Togutil) Tribal Community in Forest Conservation in Halmahera, Indonesia. International Journal Of Plant Research, 4(4A), 1-7.
Thomas, F. L., \& Kitzmiller, J. H. (2014). Genetic strategies for reforestation in the face of global climate change. Forest Ecology Management, 50(2),153-169.

Wibowo, H. A., Wasino, W., \& Setyowati, D. L. (2012). Local Wisdom in Maintaining the Environment (Case Study of the Community in Colo Village, Dawe District, Kudus Regency) (In Indonesia). Journal of Educational Social Studies, 1(1), 25-30

Youn, Y. C. (2009) Use of forest resources, traditional forest-related knowledge and livelihood of forest dependent communities: Cases in South Korea. Forest Ecology Management. https://doi.org/10.1016/j. foreco.2009.01.054. 